\title{
Is Foreign Employment a Preferred Informed Choice among Households? Evidence from Nepal
}

\author{
Bishnu Prasad Sharma, PhD \\ Associate professor of Economics at Patan Multiple Campus, Tribhuvan University, Nepal
}

\begin{abstract}
Foreign employment is one of the most significant phenomena impacting a wide range of dimensions in South Asian economies that characterize a large population out-migrating for work. whether sending a member for foreign employment a preferred informed choice of households in such economies, is not known. This paper aims to examine this research question using a binary logit model using indicators of household informed decision making, leadership qualities and the access to social networks. The findings indicated that foreign employment is not a preferred choice of households but is primarily the decision of the individual to go for foreign employment rather remain unemployed and economically insecure at home. Further analysis revealed that outstanding loans were higher, and the loans paid last year were also higher for foreign employment households compared to non-foreign employed households. The mean per capita consumption of households with foreign employed member were not statistically different than those of non-foreign employed households indicating no significant welfare gain for a majority of foreign employed labour households.
\end{abstract}

Keywords: foreign employment; preferred informed choice; logit model

JEL Codes: C35, D130, J61,

\section{INTRODUCTION}

Labour migration for employment is one of the most significant economic phenomena with more than one third of households in Nepal having a family member migrated for foreign employment abroad, the largest among South Asian countries (Bossavie \& Denisova, 2018). Migration is often a dilemma for policy makers (Ozden et al., 2018). While migration for remittance helps millions in creating a better life for themselves and their families, there is a huge resistance against migrants arguing it to raise unemployment, crimes and pressures on social services at the destination countries. On the part of the country of origin, migration is considered to bring back revenue, but at the same time leads to labour shortage, loss of brain and working hands and other socio-economic imbalances (Bossavie \& Denisova, 2018). Whether sending a member for foreign employment, is a preferred choice of household among countries of origin or not is known. 
According to four months data at the end of 2019, the highest remittance receipt of Nepal from formal sources was from Qatar (18\%) followed by India (14\%) and United Arab Emirates [UAE], 13\%). The informal sources also constitute a large share. According to the Nepal Living Standard Survey 2010/11, around 56 percent households in Nepal received remittance income. As a result, the poverty incidence was around 31 percent in 2010/11 which has now fallen to around 19 percent (Nepal Rastra Bank, NRB, 2020). The updated figure of remittance recipient households is not available.

A large body of literature exists on the determinants of decision to migrate for remittance that include the macro-economic factors in destination countries (Simpson 2017; Bossavie \& Denisova, 2018). The pursuit of better jobs and higher wages, particularly the wage differential, is considered the key determinant of migration for individuals who decide to migrate. Specifically, economic costs and benefits are critical determinants of foreign employment decision. There are strong evidences that show that people move from low wage to high wage locations and in search of superior current and future employment opportunities. Among low skilled labour, physical and cultural distances are powerful deterrents that restrict their movement to neighbouring countries or within the same region (Ozden et al., 2018).

Studies have identified an interface of several factors-who makes the decision for foreign employment; what is the motivation for decision and; what regulatory environment are the determining factors in undertaking such actions (Bauer et al., 2005). Foreign employment and the remittance they send back has important implications on addressing poverty at the country of origin too. Studies have shown that poverty status measured in terms of poverty incidence and poverty gaps have fallen due to remittance income from abroad (Chukwuone et al., 2012).

Labour migration with and without intention to return to the country of origin create a distinction between temporary and permanent migration. The two need to be analyzed separately. The movement of labour with the intention to return after some specified time is considered as foreign employment for analytical purpose (Bossavie \& Denisova, 2018). This paper focuses only on foreign employment rather than the labour force migrating for permanent settlement to other countries and aims to explore whether it is the preferred informed choice of households to send its member for foreign employment or not.

The findings of this study can have important implication for policy makers in designing appropriate policies for utilizing labour force within the country, utilizing remittance receipts for improving capacity of the future generation through human 
resource development, economic security for returnees and backstopping at the local level to improve the welfare of such households.

\section{LITERATURE REVIEW}

Massey et al. (1993) provide the earliest comprehensive review of the theories of international migration. This paper covers an extended analysis covering from the neoclassical macro-economic theory of international demand and supply of labour along with the neoclassical micro theory of the costs and benefits perceived by labour for international movement. Moving further, the paper examines the new economics of migration, the duel labour market theory of structural factors inherent in developed economies that cause permanent demand of labour from developing countries while the world system theory that cause the capitalist centre and the peripheral system creating a flow of population to migrate abroad. Further, the paper discusses the network theory on how expanding networks of migrants reduces costs and risks of migration till there is no further motivation to migrate. The institutional theory explains how emergence of institutions (such as the manpower agencies in the context of Nepal), which facilitate legal or illegal movement of labour driven by profit motives internationally that accelerate international movement of migrant labour.

Piesse (2014) has identified that socio-political, economic and ecological factors are the main forces driving migration for livelihood. Likewise rising economic disparity between developing countries and developed countries make labour migration beneficial due to wage differentials. Migrants can also be classified as humanitarian migrants (for instance refugees) and economic migrants (labour movement for financial consideration).

In a study by Bauer et al. (2005) on the labour migration policies of developed countries, the authors have identified that falling transportation and information cost with rising globalization as one of the reasons for labour migration. Countries differ by their immigration policies ranging from countries such as the United States that to some extent encourage family migration (diversity visa, DV, for instance) while other adopt mixed strategies, managing labour immigrants through quotas or contract labour. Migration decision on the part of the labour according to standard neoclassical model is an individual investment under perfect information. The migrant estimates the net return of the decision based on cost and benefit imputations. On the part of labour migration, Bauer et al. (2005) apprehend that there is a paucity of reliable information for analyzing the various factors, outcome and consequences of migration decisions.

In a study of migration in Nepal, Sijapati et al. (2017) has also identified several determinants of foreign employment choice. They are mainly the low premium on 
education in Nepal, wage differentials across Nepal and employment destination are the economic factors while the status society has vested to people returning from abroad and the disenchantment from political leadership as the cultural and socio-political factors driving people for foreign employment. These conclusions are, however, are not based on robust statistical tests.

Hatlebakk (2016) has also examined the intergenerational determinants of migration decisions in case of international labour migrations. The study based on Nepal Living Standard Survey, 2011 examined how previous migrations histories can influence recent migration decision. This study includes other variables such landlessness, being in Dalit ethnic community and being in hill origin, among others. The study concludes that people need a generation of stable settlement after the first migration before sending their members for employment abroad.

The most recent analysis of labour migration in Nepal has been presented by Bossavie \& Denisova (2018). The study used the Nepal Living Standard Survey (NLSS) 2010/11 national household survey data to analyze the various causes and consequences of foreign employment of youth labour in Nepal. The study identified age of the labour, educational status, consumption quintile, ethnicity, landholding size, household heads dependence on agriculture and geographical regions determining labour decision to go for foreign employment. Among important policy variables, for male youth, people with higher educational level are less likely to migrate. Compared to youths from Brahmin community, those in the Dalit and Muslim communities are more likely to go for foreign employment. Those from the Terai middle caste community are less likely to go for foreign employment. Higher the household involvement in agriculture, higher is the likelihood to go for foreign employment suggesting a push factor. Households owning at least one hectare land are less likely to migrate indicating that land inadequacy for agriculture as a push factor. For female, married females are less likely to go for foreign employment for work. Married females with higher educational level and who come from richer family and living in developed communities are more likely to migrate permanently. Agriculture characteristics are less deterministic in female foreign employment decisions decision. For both male and female, households residing outside of Kathmandu valley are more likely to go for foreign employment. Household size was not found to be an important factor in foreign employment decision.

The above review of existing literature indicates that there is a vast literature on the theories of migration. The reviewed theories are complementary and are often not contradictory, but they differ mostly in their perspectives. When we look more closely at the decision-making process of migrating households, it appears that the 
households' act of labour allocation through migration to diversify income and risks provides the most important micro-dimension of the decision-making process. Even among various micro economic theories that focuses on factors influencing migration decisions, household socio-economic characteristics have an influence on this process from the perspective of an individual migrant. However, there is clearly a dearth of cohesive literature available on whether sending a household member for foreign employment is a preferred informed choice or not among household members who remain at home. This paper aims to fill in this caveat in literature using evidences from Nepal.

\section{METHODOLOGY}

This study assumes that for a household with members in foreign employment, the decision to go for foreign employment was mainly a matter of the personal choice of the migrant labour. There is, however, another aspect too - the preference of the remaining household members including the household head. This study examines the preferences of household, socio-economic and other social capital characteristic in making opinion and informed choice among remaining household members, particularly the household head, whether they preferred their household member to go for foreign employment.

\section{Data sources}

This study is based on primary data collected for a different purpose using direct interview schedule with household head or other members in three ecological zones: mountain, hills and the Terai plains of Nepal in 2013. The survey questionnaire covered a wide range of information that included household socio-economic characteristics, such as household rooster, participation in foreign employment, land holding, main source of livelihood of the household, among others. Information also included indicators of social capital such as participation in community institutions, leadership roles through participation in the management committees of such institutions among others. Since this is a post migration survey, this study uses mainly household characteristics that are time invariant in the short run.

The sampling design consisted of a total of 210 households for each of the three ecological zone with a total of 630 households. After data cleaning and verification, a total of 614 households were finalized for analysis.

\section{Model Specification}

This paper uses binary logit model (Gujarati, 1999; Wooldridge, 2007) to examine the likelihood of households with given household socio-economic and informed decision 
indicators on the choice to prefer their member households for foreign employment. Whether the household has a member in foreign employment, or not, is a binary variable representing zero or one for non-foreign employed household and foreign employed household, respectively. Only employment abroad has been considered while people going for temporary employment to cities within the country have not been included.

Following several other studies (Bossavie \& Denisova,2018; Asia Foundation, 2013), we found that household size, literacy status of household head, gender of the household head are important variables in determining foreign employment decision. While household size is a socio-economic variable, literacy status of household head and gender status of household head are used as variables for informed household choice. Gender role in risk attitudes is shaped by social environment through socially constructed norms. As a result, the gender of the household being a male generally has more information access and capacity to take risks in patriarchal societies (Oraro et al., 2018) compared to more equality-oriented societies (Chadi \& Jirjahn, 2019). In the present study, we consider household head the person, male or female, who is mainly decisive of household financial and other household decision. Total operational landholding, wage-salary as the main source of household income are the indicators of economic determinants. Ecological belt comprises of three physiographic and socio-economic zones: the harsh climatic mountain belt has a high poverty rate; the hills as a moderate climatic and poverty area while the terai is an area adjoining the labour market of India where the highest proportion of total population living in poverty (Central Bureau of Statistics, CBS, 2011). The economically most backward and sparsely populated mountain has been used as a reference ecological zone. The involvement in social institution and leadership qualities of member of the households were considered as determining socio-psychological variables. Social capital and strong migrant networks have historically played a large role in enhancing migrant flows at the individual' migration decision (Simpson, 2017; Syafitri, 2013). In the community this study was conducted, households were compulsorily a member of the community forest user group and is not a matter of choice for them for the purpose of meeting household subsistence forest-based requirement. However, membership in additional social organization is optional and indicates the networking capacity of the household. Membership in social institutions other than community forest user group has been used as an indicator for local organizational membership.

The logit model provides the estimated probability between 0 and 1 ; for the household with its member gone for foreign employment is given by:

$E(Y i)=P(Y i)=\frac{e^{\alpha+\beta X i}}{1+e^{\alpha+\beta X i}}$ 
For a household with non-foreign employed member, the probability is:

$\mathrm{P}$ (no-foreign employed) $1-\mathrm{P}(\mathrm{Yi})=\frac{1}{1+e^{\alpha+\beta X i}}$

Where, e is the exponential function

Yi : the variable explained: the household with foreign employed member

$\beta$ : the vector of the parameters to estimate whose sign allows the interpretation of the results

$\beta_{0}$ : The constant

$\mathrm{Xi}$ : characteristics of the individual $\mathrm{i}$; it represents the vector of the explanatory

$$
\begin{aligned}
Y=\beta_{0} & +\beta_{1} \text { HH_SIZE }+\beta_{2} \text { LITERAT_HHHEAD } \\
& +\beta_{3} \text { MALE_HHHEAD }+\beta_{4} \text { WAGE_SAL_MAIN }+\beta_{5} \text { TOT_OPERAT_LAND }+\beta_{6} \text { INDIGENOUS } \\
& +\beta_{7} \text { DALIT }+\beta_{8} \text { ECOL_BELT }+\beta_{9} \text { LOCAL_ORG_MEMBER } \\
& +\beta_{10} \text { EXEC_MEMBER }
\end{aligned}
$$

Where, HH_SIZE = size of the household, LITERAT_HHHEAD $=$ HH head is literate, MALE_HHHEAD = Household head is male, WAGE_SAL_MAIN = wage and salary income is the main source of household income, TOT_OPERAT_LAND = total operational agricultural landholding of household, INDIGENOUS $=$ member of indigenous ethnic community, DALIT = Member of Dalit ethnic community, ECOL_ BELT $=1=$ mountain, $2=$ hills and 3= terai, LOCAL_ORG_MEMBER $=$ household is local organizational member, and EXEC_MEMBER = household is an executive committee member in some social organization.

Stata software was used for running the maximum likelihood estimation.

\section{MAIN FINDINGS}

Among a total of 614 households, 137 households had foreign employed members while 477 had no foreign employed members. The average households for the two categories combined was around 5 persons with a range of 1-15. On average literate households were around two third while male headed households were around 83 percent. Among the total households, around one third had wage or salary income as their main source of livelihood. Indigenous population constituted around three fifth of the total population while Dalit constituted around 10 percent. The average operational land holding was 0.6 hectares. around 76 percent of the total households 
were members of local community institutions while 12.5 percent were holding executive positions in the local community institutions.

Table 1: Summary statistics of variables used in the model $(n=614)$

\begin{tabular}{|l|l|l|l|l|l|}
\hline Variable & Category & Mean & Std. Dev. & Min & Max \\
\hline HH_SIZE & Continuous & 4.793 & 2.049 & 1 & 15 \\
\hline LITERAT_HHHEAD & Dummy & 0.663 & 0.473 & 0 & 1 \\
\hline MALE_HHHEAD & Dummy & 0.827 & 0.378 & 0 & 1 \\
\hline WAGE_SAL_MAIN & Dummy & 0.336 & 0.473 & 0 & 1 \\
\hline INDIGENOUS & Dummy & 0.580 & 0.494 & 0 & 1 \\
\hline DALIT & Dummy & 0.098 & 0.297 & 0 & 1 \\
\hline TOT_OPERAT_LAND & Continuous & 0.587 & 0.526 & 0 & 3.714 \\
\hline ECOL_BELT & categorical & 1.993 & 0.820 & 1 & 3 \\
\hline LOCAL_ORG_MEMBER & Dummy & 0.759 & 0.428 & 0 & 1 \\
\hline EXEC_MEMBER & Dummy & 0.125 & 0.331 & 0 & 1 \\
\hline
\end{tabular}

Source: Author's calculation

Looking at the maximum likelihood estimation, the regression results showed that literacy status of household head, gender of the household head being a male and the household being mainly dependent on wage-salary earner were statistically significant with negative signs. This indicates that compared to non-literate households, literate households are less likely to prefer their household member going for foreign employment. The marginal effects show that an increase in household head's literacy status by one percent is likely to reduce the preference for foreign employment by 0.06 percent (at $5 \%$ significance level). In a similar manner, household head being a male is less likely to prefer the household member going for foreign employment. The marginal effect shows that one percent increase in household head being a male reduces the likelihood of the preference of the household member for foreign employment by 0.13 percent (significant at $1 \%$ level). 
Table 2: Maximum Likelihood Estimation

\begin{tabular}{|l|l|l|l|l|l|l|}
\hline $\begin{array}{l}\text { Dependent variable } \\
\text { HOUSEHOLD } \\
\text { IN FOREIGN } \\
\text { EMPLOYMENT }\end{array}$ & Coef. & $\begin{array}{l}\text { Robust } \\
\text { Std. Err. }\end{array}$ & $\mathbf{z}$ & \multicolumn{2}{|c|}{ P>Iz| } & \multicolumn{2}{|c|}{$\begin{array}{l}\text { 95\% Conf. } \\
\text { Interval }\end{array}$} \\
\hline HH_SIZE & -0.093 & 0.060 & -1.56 & 0.119 & -0.210 & 0.024 \\
\hline LITERAT_HHHEAD & -0.494 & 0.244 & -2.03 & $\mathbf{0 . 0 4 2}$ & -0.972 & -0.017 \\
\hline MALE_HHHEAD & -1.052 & 0.280 & -3.76 & $\mathbf{0 . 0 0 0}$ & -1.601 & -0.504 \\
\hline WAGE_SAL_MAIN & -2.500 & 0.368 & -6.79 & $\mathbf{0 . 0 0 0}$ & -3.222 & -1.778 \\
\hline TOT_OPERAT_LAND & 0.183 & 0.229 & 0.8 & 0.425 & -0.266 & 0.631 \\
\hline INDIGENOUS & -0.109 & 0.267 & -0.41 & 0.682 & -0.632 & 0.414 \\
\hline DALIT & 0.472 & 0.398 & 1.19 & 0.235 & -0.307 & 1.251 \\
\hline ECOL_BELT & & & & & & \\
\hline 2 & 1.288 & 0.296 & 4.35 & $\mathbf{0 . 0 0 0}$ & 0.707 & 1.868 \\
\hline 3 & 1.160 & 0.321 & 3.62 & $\mathbf{0 . 0 0 0}$ & 0.531 & 1.788 \\
\hline LOCAL_ORG_MEMBER & 0.534 & 0.299 & 1.78 & $\mathbf{0 . 0 7 4}$ & -0.052 & 1.120 \\
\hline EXEC_MEMBER & -0.718 & 0.374 & -1.92 & $\mathbf{0 . 0 5 5}$ & -1.450 & 0.014 \\
\hline CONSTANT & -0.480 & 0.476 & -1.01 & 0.312 & -1.413 & 0.452 \\
\hline
\end{tabular}

Source: Author's calculation

The households mainly dependent on wage-salary income are also less likely to prefer foreign employment of its household member and for each percent household mainly dependent on wage-salary income reduces the likelihood of preferring foreign employment by 0.31 percent. (at $1 \%$ level of significance).

Regarding the effect of ecological zone, the findings revealed that compared to the mountain ecological zone, the hills and the terai have a higher preference for foreign employment by 0.15 and 0.13 percent respectively. The mountains are very remote in access, and the people in the hills and terai have a higher probability to go for foreign employment probably because of relatively at a better position in terms of access to education, information and employment related networks (Sharma et al., 2014).

The positive coefficients for membership in social organization showed that the effects of social networks in terms memberships in local organizations would facilitate foreign employment. The marginal effects indicated that with one percent increase in membership in social organizations, the likelihood of a household going for foreign employment increased by 0.07 percent (significant at 10 percent). Households with 
leadership position in social organizations in the form of executive position had a negative effect on foreign employment preference (significant at 10\% level). A one percent increase in households with position as executive member increases the probability of households preferring foreign employment by 0.09 percent. This might be because more smarter households with leadership qualities could see the prospects of utilizing networks to provide employment for their members within the country

Table 3: Marginal Effects

\begin{tabular}{|c|c|c|c|c|c|c|}
\hline $\begin{array}{l}\text { Dependent variable } \\
\text { HOUSEHOLD IN FOREIGN } \\
\text { EMPLOYMENT }\end{array}$ & $\mathrm{dy} / \mathrm{dx}$ & Std. Err. & $\mathrm{z}$ & $P>|z|$ & $\begin{array}{l}95 \% \mathrm{C} \\
\text { Interva }\end{array}$ & \\
\hline HH_SIZE & -0.012 & 0.007 & -1.570 & 0.116 & -0.026 & 0.003 \\
\hline LITERAT_HHHEAD & -0.062 & 0.031 & -2.000 & 0.045 & -0.123 & -0.001 \\
\hline MALE_HHHEAD & -0.133 & 0.037 & -3.610 & 0.000 & -0.205 & -0.061 \\
\hline WAGE_SAL_MAIN & -0.315 & 0.038 & -8.350 & 0.000 & -0.389 & -0.241 \\
\hline TOT_OPERAT_LAND & -0.014 & 0.034 & -0.410 & 0.682 & -0.080 & 0.052 \\
\hline INDIGENOUS & 0.060 & 0.050 & 1.190 & 0.233 & -0.038 & 0.157 \\
\hline DALIT & 0.023 & 0.029 & 0.800 & 0.427 & -0.034 & 0.080 \\
\hline ECOL_BELT & & & & & & \\
\hline 2 & 0.147 & 0.036 & 4.090 & 0.000 & 0.077 & 0.218 \\
\hline 3 & 0.126 & 0.038 & 3.360 & 0.001 & 0.053 & 0.200 \\
\hline LOCAL_ORG_MEMBER & 0.067 & 0.036 & 1.850 & 0.065 & -0.004 & 0.139 \\
\hline EXEC_MEMBER & -0.091 & 0.047 & -1.920 & 0.055 & -0.183 & 0.002 \\
\hline
\end{tabular}

Source: Author's calculation

The maximum likelihood estimate results indicated that household size, ethnicity of the household (indigenous or Dalit) have different signs but the results are not significant. The estimations were made under condition of robustness. The overall fit with Wald chi test was 92.13 and was statistically significant (p-value 0.000). The pseudo R-squared was 21 percent and can be considered sufficient with reference to the prevailing convention for cross sectional data.

Several other indicators were analyzed to shed lights on other socio-economic characteristics of the foreign employed households versus non-foreign employed households. The mean educational expenditures of the foreign employed households were relative lower than that of the non-foreign employed households and was quite surprising. Earlier studies have shown a positive effect of foreign employment has 
a positive effect on children's education through remittances (Bossavie \& Denisova, 2018). However, the mean health expenditures of the foreign employed households were higher than that of the non-foreign employed households (but not statistically significant).

The percentage share of liquified petroleum gas (LPG) fuel in household cooking, an indicator of household welfare through clean and efficient cooking energy source was higher for foreign employed households compared to non-foreign employed households (significant at 5 percent level). Borrowing of loan for household purpose was higher for non-foreign employed households compared to foreign employed households and the difference was statistically significant. However, the outstanding loan was also higher for foreign employed households (statistically non-significant difference). Interestingly, households borrowing from formal source was higher for non-foreign employed households compared to foreign employed households (with statistically significant difference).

Table 4: Mean Values And Differences of Selected Variables for Foreign Employed and Non-Employed Households

\begin{tabular}{|l|l|l|l|}
\hline Indicator variables & \multicolumn{2}{|l|}{ Mean value (std. error) } & Difference \\
\cline { 2 - 4 } & $\begin{array}{l}\text { Foreign } \\
\text { employed } \\
(\mathrm{n}=137)\end{array}$ & $\begin{array}{l}\text { Non-foreign } \\
\text { employed } \\
(\mathrm{n}=477)\end{array}$ & \\
\hline & & & \\
\hline $\begin{array}{l}\text { Educationalexpenditure of household } \\
\text { (Rs. thousand) }\end{array}$ & $11.81(2.15)$ & $18.64(2.19)$ & $-6.82(4.25)^{*}$ \\
\hline $\begin{array}{l}\text { Health expenditure of household (Rs. } \\
\text { thousand) }\end{array}$ & $22.90(10.56)$ & $15.74(2.38)$ & $7.16(7.19)$ \\
\hline Percentage share of LPG in cooking & $15.40(2.33)$ & $10.14(1.12)$ & $5.26(2.43)^{* *}$ \\
\hline $\begin{array}{l}\text { Households borrowed any loan last } \\
\text { year }\end{array}$ & $0.36(0.04)$ & $0.46(0.02)$ & $-0.09(0.05)^{*}$ \\
\hline $\begin{array}{l}\text { Households outstanding loan (Rs. } \\
\text { thousand) }\end{array}$ & $176.58(63.19)$ & $\begin{array}{l}161.1 \\
(35.45)\end{array}$ & $15.47(79.87)$ \\
\hline $\begin{array}{l}\text { Household borrows from formal } \\
\text { source (Y=1, N=0) }\end{array}$ & $0.15(0.03)$ & $0.23(0.02)$ & $-0.08(0.04)^{*}$ \\
\hline $\begin{array}{l}\text { Amount of loan paid this year (Rs. } \\
\text { thousand) }\end{array}$ & $48.79(12.03)$ & $21.05(3.41)$ & $27.74(9.06)^{* * *}$ \\
\hline Interest rate of borrowing (percent) & $22.31(1.18)$ & $19.18(1.16)$ & $3.13(2.45)$ \\
\hline $\begin{array}{l}\text { Per capita consumption of HH (Rs. } \\
\text { thousand) }\end{array}$ & $65.81(7.17)$ & $60.62(3.28)$ & $5.19(7.23)$ \\
\hline
\end{tabular}

Note: ${ }^{* *},{ }^{* *}$ and ${ }^{*}$ indicate significant at 1 percent, 5 percent and 10 percent level respectively. Source: Author's calculation 
The amount of loan paid last year was more than double for the foreign employed households compared to the non-foreign employed households indicating that foreign employed households incur large debts while sending members for foreign employment in course of payment to manpower companies and other agents. The difference was also significant at 1 percent level. Studies have shown that foreign employed households incur about 25 percent of the remittance received to pay back borrowed loans (NRB, 2016). The source of borrowing was also relatively less from formal sources for foreign employed households. The average interest rate of borrowing was also higher for foreign employed households compared to non-foreign employed households (though not statistically significantly different), due to dependence on informal sources such as traders and moneylenders. When we finally look at the mean per capita consumption, the most widely used indicator of household welfare, it was higher than foreign employed households compared to the non-foreign employed households but with the difference was not statistically significant.

\section{DISCUSSIONS}

Foreign employment has been a major source of household income for survival and income supplement for a large number of households in developing countries like Bangladesh, Nepal, India among others. Earlier studies have shown that remittance income was the only source of income for about 19 percent households in Nepal while for remaining 81 percent it supplements household income from other sources. A total of 4.6 million people out of the total population of around 30 million of Nepal have received work permit to work abroad and the proportion of male and female is approximately 9:1(NRB, 2016). This figure does not include labourers working in India informally through open boarder. These figures show the magnitude of foreign employment dependence in Nepal.

Foreign employment is a compelling choice for the majority of low educated, low skilled Nepalese labourers going for foreign employment (Sharma, 2017). One important reason for opting for foreign employment is the low marginal productivity of labour in traditional agriculture and the consequent low wages in Nepal (Sharma, 2015). The results showed that foreign employment is not a preferred choice for relatively better households in terms of literate household head, male headed household and households with wages and salary as the main source of income. This is because of the risks, uncertainties and vulnerabilities they might face in foreign land on the face of illiteracy or low literacy, lack of skills and language barriers, and high interest repayment burden at home. Previous studies have also shown that people who have gone for foreign employment are mostly unskilled labour, the real average earnings are low while the principle and interest payment they incur from informal sources in course of obtaining foreign employment are substantial (The Asia Foundation, 2013). 
The problem of adjustment of such persons in the society once they return back after several years has also been considered a sensitive issue (Bossavie \& Denisova, 2018) Despite these uncertainties, labourers go for foreign employment driven by poverty, unemployment at home, indebtedness and to secure financial solvency (The Asia Foundation, 2013). Ethnicity and operational landholding size had no effect on the foreign employment choice decision.

In addition, it has been observed from quite a number of earlier studies that going for foreign employment is not a preferred option for remaining family members among working people, but a compulsion created by lack of economic opportunities at home. Agricultural lands are becoming fallow, productivity declining and degradation of land due to shortage of manpower to work in family farms in most areas threatening food security in the rural areas (Schwilch et al., 2017; Jaquet et al., 2019; KC \& Race, 2020).

The findings indicate that the choice to go for foreign employment is primarily the decision of the individual rather remain unemployed and economically insecure at home. Earlier studies have also found that the decision to go for foreign employment is mainly driven by external pull factors such as economic and other forces in destination countries, rather than by forces in Nepal (Bossavie \& Denisova, 2018; Massey et al., 1993). More importantly, it is the mainly the individual person who makes foreign employment decision in search for a better life rather than the choice of the other members of the household (Ozden et al., 2018). When households cannot persuade their family members to remain and work in the country either by providing them the means for livelihood, rational household members will have no choice but to support within their capacity to the individual members who decides to go for foreign employment. Such support takes place through finance and other support with the expectation that the migrant will repay back the cost of financing along with income flow for the household in the future.

Studies have also shown that assurance of secure employment abroad and inducement to migrate by an agent, family or friend, demonstration effect and the effect of witnessing successful migration of other people in the community are powerful factors (The Asia Foundation, 2013). The data, in this study was, however, limited in terms of the coverage of the individual characteristics and other psychological aspects of the migrant worker.

The findings from further comparative analysis of foreign employed households versus non-foreign employed households indicates that foreign employed households incur higher debts and debt repayment from the remittance received. It also revealed 
that there is some welfare improvement such as higher health expenditure and the use of LPG cookstoves for household cooking made probably made available by increased household income from remittance sent by these workers. LPG cook stoves are considered an improvement over traditional fuel due to their convenient and clean nature as shown by previous studies on energy transition and energy stacking (Coelho et al. 2018; Sharma, 2018; Sharma et al., 2019). Lower educational expenses of foreign employed households compared to non-foreign employed households (though not statistically significant) might be indicative of conspicuous consumption dominating over investment on human resource development for the future. The most widely used indicator of household consumption, the per capita consumption of food and nonfood items also indicated that though economically it is higher for foreign employed household compared to the non-foreign employed households, the difference is not statistically significant. There is a possibility that foreign employed households receive remittance incomes but a significant share of it is extracted by local traders, money lenders in the form of interest and principle payment among others who have been benefitted more by people sending remittance from abroad.

Regarding the limitations of the study, the sample of foreign employed households and non-foreign employed households were not equal due to non-proportional sampling design. The results could have been more robust with equally large number of foreign employed households compared to non-foreign employed households. In addition, this study is a post movement survey such that the member of the foreign employed households has already left the family. Thus, several individual characteristics of the person who has gone for foreign employment could not be included in the analysis, which could have enriched the findings even more. The findings could have been better if baseline date before movement for foreign employment could be obtained. These limitations provide a scope for further studies in the future.

\section{CONCLUSIONS}

The findings of the study revealed that sending household member for foreign employment is not a preferred choice of informed households. Literate, male headed households and households in leadership roles in community were found to prefer their family members not going for foreign employment. Foreign employment has been found to be characterized by exploitations, low pays, insecurity and highly risky work environment for most of the Nepalese labour migrants by human right institutions too (Amnesty International, 2011) From a macro-economic perspective also, studies that cover several countries have shown that remittance can contribute significantly to long run development of the economy only in relatively developed countries, rather than low income countries (Matuzeviciute \& Butkus, 2016). 
Given the findings that sending members for foreign employment is not a preferred informed choice of households and is a distressing social phenomenon, it is through gainful employment at home that can attract individuals to work in the home country rather than go for foreign employment. A number of previous studies have also highlighted that education, skill trainings, entrepreneurship development opportunities along with financial provision for investment in packages can make foreign employment unattractive compared to costs and uncertainties of employment abroad (Bossavie \& Denisova, 2018; Sijapati, 2014). The utilization of remittance brought home by the present generation if utilized efficiently through effective planning can also to some extent enable the future generation with education, skills and other requirements to make its citizens work in their own country and contribute to home economy in the future.

\section{REFERENCES}

Amnesty International. (2011). False promises: Exploitation and forced labour of Nepalese migrant workers. Amnesty International, UK

Bauer, T. K., Haisken-DeNew, J. P., \& Schmidt, C. M. (2005). International labour migration, economic growth and labour markets: The current state of affairs. The New Demographic Regime: Population Challenges and Policy Responses, United Nations Publication, Geneva, 111-135.

Bossavie, L., \& Denisova, A. (2018). Youth labor migration in Nepal. The world Bank.

Chadi, C., \& Jirjahn, U. (2019). Does Society Influence the Gender Gap in Risk Attitudes? Evidence from East and West Germany (No. 311). GLO Discussion Paper.

Chukwuone, N. A., Amaechina, E., Enebeli-Uzor, S. E., Iyoko, E., \& Okpukpara, B. (2012). Analysis of impact of remittance on poverty in Nigeria. PEP Working Paper serie No. 2012-09

Coelho, S. T., Sanches-Pereira, A., Tudeschini, L. G., \& Goldemberg, J. (2018). The energy transition history of fuelwood replacement for liquefied petroleum gas in Brazilian households from 1920 to 2016. Energy Policy, 123, 41-52.

Foundation, The Asia. (2013). Labour migration trends and patterns: Bangladesh, India, and Nepal https://asiafoundation.org/resources/pdfs/ LabourMigrationTrendsandPatternsBangladeshIndiaandNepal2013.pdf

Gujarati, D. N. (1999). Essentials of econometrics, International Edition 1999. Irwin/ McGraw-Hill

Hatlebakk, M. (2016). Inter-generational determinants of migration decisions: The case of international labour migration from Nepal. Oxford Development 
Studies, 44(1), 93-112. http://dx.doi.org/10.2139/ssrn.2367404 https://wol.iza.org/ uploads/articles/373/pdfs/demographic-and-economic-determinants-of-migration. pdf? $\mathrm{v}=1 \quad$ https:/www.uni-kassel.de/upress/online/frei/978-3-86219-314-1.volltext. frei.pdf

Jaquet, S., Kohler, T., \& Schwilch, G. (2019). Labour migration in the middle hills of Nepal: Consequences on land management strategies. Sustainability, 11(5), 1349.

KC, B., \& Race, D. (2020). Outmigration and Land-Use Change: A Case Study from the Middle Hills of Nepal. Land, 9(1), 2. https://doi.org/10.3390/land9010002

Lucas, R. E. (2005). International migration and economic development: Lessons from lowincome countries. Edward Elgar Publishing.

Massey, D. S., Arango, J., Hugo, G., Kouaouci, A., Pellegrino, A., \& Taylor, J. E. (1993). Theories of international migration: A review and appraisal. Population and development review, 431-466. DOI: 10.2307/2938462

Matuzeviciute, K., \& Butkus, M. (2016). Remittances, development level, and long-run economic growth. Economies, 4(4), 1-20. https://doi.org/10.3390/ economies 4040028

NRB. (2016). Saving and investment behaviour of remittance recipient households. Nepal Rastra Bank. Kathmandu.

Oraro, T., Ngube, N., Atohmbom, G. Y., Srivastava, S., \& Wyss, K. (2018). The influence of gender and household headship on voluntary health insurance: The case of NorthWest Cameroon. Health Policy and Planning, 33(2), 163-170.

Ozden, C., Wagner, M., \& Packard, M. (2018). Moving for Prosperity: Global migration and labor markets. Policy Research Report Overview, World Bank Group, 15. The World Bank, Washington, DC.

Piesse, M. (2014). Factors influencing migration and population movements-part 1 Strategic Analysis Paper, Future Directions International. https://www.futuredirections.org. au/wp-content/uploads/2014/10/FDI_Strategic_Analysis_Paper_Migration_and_ Population_Movements_2.pdf

Schwilch, G., Adhikari, A., Jaboyedoff, M., Jaquet, S., Kaenzig, R., Liniger, H., ... \& Upreti, B. R. (2017). Impacts of outmigration on land management in a Nepali mountain area. In Identifying emerging issues in disaster risk reduction, migration, climate change and sustainable development (pp. 177-194). Springer, Cham.

Sharma, A., Parikh, J., \& Singh, C. (2019). Transition to LPG for cooking: A case study from two states of India. Energy for Sustainable Development, 51, 63-72. 
Sharma, B. (2017). Socio-economic problems of remittance economy: The case of Nepal. Journal of Advanced Management Science, 5(4),285-290

Sharma, B. P. (2013). Measuring the price of labour in agricultural economies: The shadow wage rate. Economic Journal of Development Issues, 15 (1\&2), 24-35. . (2018). Household fuel transition and determinants of firewood demand in Nepal. Economic Journal of Development Issues, 25 \& 26, 83-95.

Sharma, S., Pandey, S., Pathak, D., \& Sijapati-Basnett, B. (2014). State of migration in Nepal. Kathmandu: Centre for the Study of Labour and Mobility.

Sijapati, B. (2014). Enhancing employment-centric growth in Nepal. ILO, Kathmandu.

Simpson, N. B. (2017). Demographic and economic determinants of migration. IZA World of Labor.

Syafitri, W. (2012). Determinants of labour migration decisions: The case of East Java, Indonesia. A PhD thesis published by University of Kassel, Kassel University Press, Germany.

Wooldridge, J.M (2007). Introductory Econometrics: A Modern Approach. Thomson SouthWestern. First Indian Reprint. 